\title{
Przekłady Biblii na język włoski (XV-XIX wiek)
}

Włochy nie należą do krajów, w których tłumaczenie Biblii stanowito albo początek własnej literatury, albo jedno $z$ arcydzieł szczególnie cenionych $^{1}$. Nie oznacza to jednak, że Biblia nie była na przestrzeni wieków obiektem zainteresowania i to nie tylko specjalistów, ale i zwykłych wiernych. Ramy tego artykułu nie pozwalają, nawet na bardzo pobieżne, omówienie miejsca Biblii w kulturze, sztuce czy nauce włoskiej, dlatego zainteresowanych tym zagadnieniem odsyłamy do szczegółowych opracowań ${ }^{2}$.

Najstarsze rękopisy Biblii w języku włoskim datowane są na XIV wiek$^{3}$. Powstały one na zasadzie łączenia wcześniejszych cząstkowych wydań, na ogół anonimowych, zawierających przekłady poszczególnych

${ }^{1}$ Por. A. Penna, La lettera di Dio. Presupposti di esegesi biblica, Brescia 1952, 244-245. Panoramę wydań książek o tematyce religijnej we Włoszech w okresie 1600-1900 prezentuje P. Stella, Produzione libraria religiosa e versioni della B. in Italia tra età dei lumie crisi modernista, [w:] Cattolicesimo e lumi nel Settecento Italiano, a cura di M. Rosa, Roma 1981, 125 (na pierwszym miejscu są dzieła św. Alfonsa Liguoriego, katechizmy Belarmina, niektóre dzieła św. Agustyna; a z tekstów biblijnych dopiero Biblia Martiniego odnotuje spory sukces).

${ }^{2}$ Por. np. P. Stefani, La radice biblica - La Bibbia e i suoi influssi nella cultura occidentale, Torino 2003.

${ }^{3}$ Por. A. Vaccari, Bibbia, [w:] Enciclopedia Italiana, Roma 1930, 899-903; G. Ricciotti, Bibbia, [w: Enciclopedia Cattolica, Roma, 1556-1563; P. J. Achtemeier, Bibbia in lingua italiana, [w:] Il Dizionario della Bibbia, P. J. Achtemeier, P. Capelli, Bologna 2003, 134; F. Spadafora, Bibbia, [w:] Dizionario biblico, Roma 1957², 87; S. Minocchi, Italiennes (versions), [w:] Dictionnaire de la Bible, 1022-1038; I. Carini, Traduzione italiana della Bibbia, [w:] F. Vigouroux, N. C. Bacuez, Manuale biblico, S. Pier d'Arena 1894, I, 263-330; E. Barbieri, Le Bibbie italiane del Quattrocento e del Cinqucento. Storia e bibliografia, Milano 1992; La Bibbia nell'epoca moderna e contemporanea, a cura di R. Fabris, Bologna 1992. 
ksiąg lub grup ksiąg ${ }^{4}$ Zachowane rękopisy wskazują jednoznacznie, że w pierwszej kolejności tłumaczono teksty przydatne do mszy świętej i obrzędów liturgicznych, dopiero później - całe księgi. Można odnieść wrażenie, że są to raczej poszerzone i wyjaśniające parafrazy tekstów biblijnych niż tłumaczenia w sensie dosłownym.

Pierwszych tłumaczeń dokonywano z łacińskiej Wulgaty ${ }^{5}$ (niekiedy może chodzić o jej wersję wcześniejszą niż ta ustalona na Uniwersytecie Paryskim w początkach XIII wieku, co pozwala przypuszczać, że niektóre z tych tłumaczeń mogłyby sięgać nawet jej początków ${ }^{6}$ lub z języków d'oc (starożytny język francuski) i (lub) d'oïl (starożytny język prowansalski). Zbiory tych rękopisów dziś należą do rzadkości i prawie zawsze (z powodu niekompletności zbioru pierwotnego lub niszczącego upływu czasu) brakuje w nich którejś z ksiąg7.

Pomimo że pierwsze tłumaczenia miały na ogół związek z grupami heretyckimi, sam tekst (zwłaszcza Nowego Testamentu) nie był przedmiotem manipulacji doktrynalnych; z tłumaczeń tych korzystali zatem także dominikańscy i franciszkańscy kaznodzieje ${ }^{8}$.

Za pierwszy tekst biblijny przetłumaczony na język włoski można by uznać Splonamento degli proverbi di Salomone Gerardo Pontecchio z Kremony, gdyby język tego przekładu nie czerpał z mądrości hebrajskich jedynie bodźca i wzoru. Jednak mimo że nie jest to tłumaczenie w dzisiejszym rozumieniu tego słowa, tekst ten pozostaje typowy dla najstarszych tłumaczeń, i to w trzech aspektach: czasu, dialektu, treści ${ }^{9}$.

Autorzy pierwszych tłumaczeń nie są nam znani; dopiero w XIV wieku niektórzy z nich podpisywali się imionami, np. Domenico Cavalca,

${ }^{4}$ Przede wszystkim Ewangelii, psalmów, ksiąg mądrościowych, A pokalipsy. Najczęściej tłumaczona jest Księga Przysłów - por. C. Buzzetti, C. Ghidelli, La traduzione della Bibbia nella Chiesa italiana. Il Nuovo Testamento, Cinisello Balsamo 1998, 107.

${ }^{5}$ Od łac. vulgatus - rozpowszechniony, przyjęty przez ogół. Terminem tym określa się tłumaczenie Pisma Świętego dokonane przez św. Hieronima z polecenia papieża Damazego I. Nie wszystkie księgi tłumaczył bezpośrednio z języków oryginalnych. Gdy chodzi o Ewangelie, poprawił już istniejący przekład starołaciński (Vetus Latina).

${ }^{6}$ Por. A. Vaccari, Bibbia, art. cyt., 899.

${ }^{7}$ Zachował się jeden prawie kompletny egzemplarz Biblii w języku włoskim, który przechowywany jest w Bibliothèque Nationale w Paryżu, rkps it. 1-2 (XV wiek).

${ }^{8}$ Por. P. J. Achtemeier, Bibbia in lingua italiana, art. cyt., 134.

${ }^{9}$ Por. A. Vaccari, Bibbia, art. cyt., 899. 
Remigi d'Ardigno de'Ricci, Ghinazzone de Siena, Iacopo da Voragine, Iacopo Passavanti. Do rzeczywistych przekładów Biblii na język włoski można zaliczyć jedynie dzieło pierwszego $\mathrm{z}$ nich ${ }^{10}$, pozostałym bowiem przyświecały cele wyłącznie literackie ${ }^{11}$. Dopiero wydania drukowane przyjęło się uważać we Włoszech za właściwe przekłady na język narodowy ${ }^{12}$.

Charakter przekładu zależy w znacznym stopniu od umiejętności tłumaczy, dlatego wartość poszczególnych rękopisów jest różna ${ }^{13}$.Z powodu zbyt wielkiej służalczości wobec oryginału łacińskiego wspólnego dla nich wszystkich, wartość tych prac jest zdecydowanie niższa ${ }^{14}$, niż może się to wydawać przy pobieżnej lekturze.

Rozkwit przekładów na język ludowy osiągnął szczyt między XIII i XIV wiekiem i stanowił decydujący czynnik dla ukształtowania się syntaksy prozy włoskiej ${ }^{15}$. Niewiele wiemy na temat linii ewolucyjnej,

${ }^{10}$ Trudno jednak rozstrzygnąć, czy był tłumaczem, czy tylko recenzentem wcześniejszych wydań.

${ }^{11}$ Pozostali, zwłaszcza dwaj ostatni, nie są znani historii tradycji rękopisów, por. G. Ricciotti, Bibbia, art. cyt., 1557.

${ }^{12}$ Por. A. Vaccari, Bibbia, art. cyt., 900, zamieszcza wykaz rękopisów zawierających całą Biblię, Stary Testament, Nowy Testament w całości oraz poszczególne księgi oddzielnie. Dokładną listę rękopisów podaje G. Danieli, La Bibbia..., [w:] La Bibbia in italiano tra medioevo e rinascimento. Atti del Convegno internazionale, Firenze, Certosa del Galluzzo, 8-9 novembre 1996, a cura di L. Leonardi, Tavarnuzze-Firenze 1998, 417-430.

${ }^{13}$ Por. La Bibbia in italiano..., dz. cyt. Od roku 1992 Fondazione Ezio Franceschini e l'Ecole Française de Rome prowadzą poszukiwania przekładów Biblii na język włoski w okresie od początku do 1500 roku, aby stworzyć nowy spis i katalog źródeł manuskryptowych różnych tłumaczeń. Takie poszukiwanie ma zagwarantować solidne i rygorystyczne podstawy filologiczne do naukowych badań kontekstu społeczno-religijnego i literackiego, w których powstawały przekłady. Podstawowe zasady tego projektu zostały opublikowane wraz z pierwszym wykazem manuskryptów w: La Bible italienne. Prémices d'une enquète en cours, „Mélange de l'ecole française de Rome. Moye Age” 105 (1993), 825-886. Od tej publikacji zdecydowano się przebadać wszystkie kodeksy, które zawierają choćby jedną księgę przetłumaczoną w całości, gromadząc mikrofilmy w siedzibie fundacji i tworząc z nich fiszki opisowe, które pozwolą na stworzenie katalogu rękopisów.

${ }^{14}$ Por. A. Vaccari, Bibbia, art. cyt., 901.

${ }^{15}$ Por. C. Segre, I volgarizzamenti del Due e Trecento, [w:] Lingue, stile e società, Mediolan 1963, 49-70; C. Delcorno, Produzione e circolazione del volgarizzamaneti religiosi tra medioevo e rinascimento, [w:] E. D’Antonio, La traduzione..., dz. cyt., 3-4. Rozróżnienia i zdefiniowania terminów „volgarizzare" i ,tradurre" dokonał G. Folena, Volgarizzare e tradurre, [w:] La traduzione. Saggi e testi. Atti del Convegno di studi sulla traduzione, Trieste 1973, 57-120. 
późniejszych przyśpieszeń i zastojów w procesie przekładów tekstów religijnych, przede wszystkim w XV i XVI wieku, ale można uznać, że jest ona paralelna do ewolucji tłumaczeń tekstów klasycznych, niekiedy się z nią krzyżuje, nigdy jednak się z nią nie miesza ${ }^{16}$.

Poniżej omówimy w porządku chronologicznym wszystkie najważniejsze przekłady Biblii, które zostały wydane drukiem w języku włoskim w okresie od początku XV do końca XIX wieku (jest ich 8), nie uwzględnimy jednak z założenia tłumaczeń i przekładów mało rozpowszechnionych lub opracowań o charakterze częściowym lub specjalistycznym (np. tylko Ewangelie, tylko Psalmy, dla dzieci itp.).

Informacje na temat poszczególnych wydań zostały ujęte w sposób schematyczny w celu łatwiejszego ich porównywania i zawierają najważniejsze dane: nazwę lub tytuł dzieła; imię i nazwisko autora; miejsce i datę wydania; nazwę wydawcy; nazwiska tłumaczy, redaktorów; źródła tłumaczenia; charakterystykę edycji; ewentualne inne uwagi.

\section{Wiek XV}

Biblia Malermi ${ }^{17}$. Bibbia dignamente vulgarizzata per il clarissimo religioso duon Nicolao Malermi Veneziano..., zwana też Bibbia d'agosto; autor: Nicolò Malermi ${ }^{18}$ (ok. 1422-1481), kameduła; miejsce i data: Wenecja, 1 sierpnia 1471 roku; wydawca: Vindelino ze Spiry; źródła: tekst oparty na tłumaczeniach XIV-wiecznych.

Autor był raczej kompilatorem, niż tłumaczem. Słownictwo i dialekt toskański zastąpił weneckim. Zabieg ten w pewien sposób obniżył wartość języka czternastowiecznego, który bez wątpienia stanowił o wartości dzieła. Powstał utwór bardziej jednorodny niż w rękopisach, które leżały u jego podstaw, dokładniejszy, ale twardszy i nieco chropowaty w warstwie językowej. Edycja składała się z dwóch tomów. Tekst na stronie rozłożony był w dwóch kolumnach. Dzieło zostało przyjęte

${ }^{16}$ Por. C. C. Delcorno, Produzione e circolazione del volgarizzamaneti religiosi tra medioevo e rinascimento, art. cyt., 3.

${ }^{17}$ Por. A. Vaccari, Bibbia, art. cyt., 901; G. Ricciotti, Bibbia, art. cyt., 1557-1558; P. J. Achtemeier, Bibbia in lingua italiana, art. cyt., 34; F. Spadafora, Bibbia, art. cyt., 87.

${ }^{18}$ Albo Mallermi, Malerbi, Manerbi (por. A. Vaccari, Bibbia, art. cyt., 901); Malherbi, Manermi (por. G. Ricciotti, Bibbia, art. cyt., 1558); por. P. J. Achtemeier, Bibbia in lingua italiana, art. cyt., 34; F. Spadafora, Bibbia, art. cyt., 87. 
bardzo życzliwie. O jego popularności świadczy jedenaście wydań w okresie inkunabułów i prawie dwadzieścia w okresie XVI wieku (niektóre z poprawkami innych autorów, np. dominikanina Mariano z Wenecji, z 1447 roku). Wiele z tych wydań zostało ozdobionych drzeworytami ${ }^{19}$. Biblia Jensoniana ${ }^{20}$. Bibbia d'ottobre - autor: nieznany, nazwa wydania pochodzi od francuskiego typografa i drukarza Nicolò Jensona; miejsce i data:Wenecja, 1 października 1471 roku; źródła: tekst oparty na tłumaczeniach czternastowiecznych, tam, gdzie występowały w nich braki, autor korzystał z Bibbia d'agosto.

Edycja naśladuje co do litery wydanie Malermiego. Mimo że przy przekładzie korzystano z rękopisów i jest ona im wierna, nie może uchodzić za typowy przykład Biblii XIV-wiecznej. Oba wydania (Malermiego i Jensona) są zgodne co do Nowego Testamentu i psalmów, wykazują natomiast spore różnice w przekładzie Starego Testamentu. Publikacja Jensona nie zyskała zbytniej popularności. W wiekach XVI-XVII miała tylko jedno wydanie ${ }^{21}$. Obrońców i propagatorów zyskała dopiero w pierwszej połowie XIX wieku, kiedy wzrosło zainteresowanie językami starożytnymi ${ }^{22}$. Biblia Jensoniana nie ma znaczenia dla krytyki biblijnej, ma natomiast wartość dla historii języka włoskiego, chociaż przypisywanie jej w tym względzie zbyt wielkiej wagi jest sporą przesadą ${ }^{23}$.

${ }^{19}$ Jedno z późniejszych wydań, które ukazało się w 1771 roku w Wenecji (7 tomów), choć nosi jego imię, tak naprawdę ma za autora Alvise'a Guerrę, prof. z Padwy. Praktycznie stworzył on zupełnie nowe dzieło, tłumacząc tekst bądź z Wulgaty, z języka hebrajskiego bądź z przekładu Deodati (Diodati) - jego autorstwa są np. wszystkie przypisy na końcu każdego tomu.

${ }^{20}$ Por. A. Vaccari, Bibbia, art. cyt., 901; G. Ricciotti, Bibbia, art. cyt., 1558; P. J. Achtemeier, Bibbia in lingua italiana, art. cyt., 134; F. Spadafora, Bibbia, art. cyt., 87.

${ }^{21}$ Por. A. Vaccari, Bibbia, art. cyt., 901.

${ }^{22} \mathrm{~W}$ roku 1846 Società veneta dei bibliografi zaczęła wydawać drukiem Bibbia volgare, testo di lingua secondo l'edizione del 1471 di Nicolò Jenson. Z powodu trudności nie tylko z władzami kościelnymi, ale i z drukarnią wydania nie dokończono. Wydano jedynie Księgę Powtórzonego Prawa. Wszystkie egzemplarze zostały jednak bądź zniszczone w drukarni, bądź się zagubiły. W tym samym czasie (1853), korzystając w lepszy sposób z rękopisów, podobną próbę przekładu podjął Stefano Ros. Niestety skończyło się jedynie na przygotowaniach. Całość wydał dopiero C. Negroni w latach 1882-1887 w Bolonii pod tytułem: La Bibbia volgare secondo la rara edizione del I ott. MCCCCLX X I. Edycja liczyła dziesięć tomów.

${ }^{23}$ Por. G. Ricciotti, Bibbia, art. cyt., 1558. 


\section{Wiek XVI}

Biblia Brucioli ${ }^{24}$. La Bibbia, quale contiene isacri libridel Vecchio Testamento tradotti nuovamente da la hebraica verità... Coi divini libridel Nuovo Testamento - autor: Antonio Brucioli (ok. 1498-1556), florentczyk; miejsce i data: Wenecja 1530 (Nowy Testament), 1532 (cała Biblia); wydawca: Lucantonio Giunti; źródła: autor posługiwał się przekładem łacińskim dominikanina Sante Pagnino z 1527 roku (Stary Testament) i Erazma z Rotterdamu z 1516 roku (Nowy Testament) ${ }^{25}$.

Jest to pierwszy przekład na język współczesny dokonany przez jednego autora ${ }^{26}$.Zarazem jest to przynajmniej w niektórych fragmentach pierwsza Biblia na Zachodzie, która odbiega od interpretacji Wulgaty. Autor nie korzystał z tekstów w językach oryginalnych (mimo informacji mówiącej o tym na stronie tytułowej), dlatego jego przekład nie ma wielkich wartości naukowych. Styl przekazu surowy, szorstki, chropowaty. Edycja była wznawiana, także z komentarzem samego autora ${ }^{27}$. W opracowaniu dostrzegalne są wpływy protestanckie, czego wynikiem było umieszczenie dzieła $\mathrm{w}$ indeksie ksiąg zakazanych ${ }^{28}$; autor nigdy jednak łączności z Kościołem nie zerwał. Od 1538 roku pojawiały się w obiegu także katolickie wersje tego przekładu. Wydanie poprawione i uszlachetnione przez Filippa Rusticiego ${ }^{29}$ do czasów Deodati (Diodati) pozostawało oficjalną biblią protestantów, którzy wyemigrowali z Włoch ${ }^{30}$.

${ }^{24}$ Por. A. Vaccari, Bibbia, art. cyt., 902; G. Ricciotti, Bibbia, art. cyt., 1558; P. J. Achtemeier, Bibbia in lingua italiana, art. cyt., 134; F. Spadafora, Bibbia, art. cyt., 87.

${ }^{25}$ Por. G. Ricciotti, Bibbia, art. cyt., 1557.

${ }^{26}$ Marcin Luter uczynił to dopiero dwa lata później. Poza tym Biblia niemiecka opublikowana przez niego w Zurychu w 1529 roku była jego autorstwa tylko w 2/3. Warto zauważyć, że Włosi byli pierwszym z narodów europejskich, którzy w początkach XVI wieku chcieli mieć przekład na język ojczysty oryginalnych tekstów biblijnych.

${ }^{27}$ Por. A. Vaccari, Bibbia, art. cyt., 902. Autor współpracował ze znanym gramatykiem i filologiem żydowskim Elią Levitą (1469-1549) - por. P. J. Achtemeier, Bibbia in lingua italiana, art. cyt., 134.

${ }^{28} \mathrm{G}$. Ricciotti, Bibbia, art. cyt. i F. Spadafora, Bibbia, art. cyt. jako datę umieszczenia dzieła na indeksie podają 1559 rok, a P. J. Achtemeier, Bibbia in lingua italiana, art. cyt. - 1554 rok.

${ }^{29}$ Wydane w Genewie w 1562 roku przezF. Durone, por. A. Vaccari, Bibbia, art. cyt., 902.

${ }^{30}$ F. Spadafora, Bibbia, art. cyt., 87. 
Biblia Marmochini $i^{31}$. Bibbia nuovamente tradotta da la Hebraica verità in lingua Thoscana per Maestro Sante Marmochino Fiorentino dell'ordine dei Predicatori - autor: Sante Marmochini, dominikanin z klasztoru św. Marka w Wenecji; miejsce i data: Wenecja 1538; wydawca: Lucantonio Giunti.

Należy wyraźnie zaznaczyć, że Marmochini jedynie poprawił to, co Brucioli przetłumaczył z Wulgaty. W obu przypadkach mamy do czynienia z tłumaczeniem z Pagininiego, tyle że dominikanin był wierniejszy oryginałowi od swego poprzednika ${ }^{32}$. Co do typu i formy zewnętrznej dzieło przypominało wydanie Brucioliego ${ }^{33}$. Edycja nie zyskała jednak większej popularności. W przypadku tekstu Nowego Testamentu autor włączył w swoje dzieło tłumaczenie swojego współbrata: Nuovo Testamento tradotto in lingua toscana dal R. Padre fra Zaccheria de l'ordine de' Predicatori $i^{34}$; dokonane zostało z języka greckiego w konfrontacji z tekstem Erazma i Wulgaty. Biblia w całości (autorstwa obu dominikanów) miała tylko jedno ponowne wydanie ${ }^{35} \mathrm{~W} 1545$ roku. W tym samym czasie ukazały się kolejne częściowe edycje Biblii, wśród których warto zauważyć wydanie dwujęzyczne włosko-francuskie ${ }^{36}$. Zawiera ono tekst włoski, w którym po raz pierwszy zastosowano podział na rozdziały i wersety.

Dekrety Trydenckie. Kwestią rozpowszechniania tłumaczeń Biblii w językach narodowych Kościół zajął się 8 kwietnia 1546 roku na IV sesji Soboru Trydenckiego, wydając dekret dogmatyczny definiujący kanon Pisma Świętego oraz dekret dyscyplinarny stwierdzający, że oficjalnym tekstem biblijnym w liturgii i w nauczaniu Kościoła ma być wyłącznie Wulgata $^{37}$. Te dwie decyzje zostały sformułowane w sposób bardzo wy-

${ }^{31}$ Por. A. Vaccari, Bibbia, art. cyt., 902; G. Ricciotti, Bibbia, art. cyt., 1559; F. Spadafora, Bibbia, art. cyt., 87.

${ }^{32}$ Por. A. Vaccari, Bibbia, art. cyt., 902.

${ }^{33}$ Sam autor twierdził, że dokonał swego dzieła w 22 miesiące.

${ }^{34}$ Wydane w Wenecji w 1536 roku przez Lucantonio Giunti, por. A. Vaccari, Bibbia, art. cyt., 902.

${ }^{35}$ Wydane przez Lucantonio Giunti. W tej edycji Księga Hioba i Księga Psalmów zostały zastąpione nowym przekładem nieznanego autora. Natomiast Nowy Testament drugiego z autorów samodzielnie miał kilka wydań.

${ }^{36}$ Wydane w 1552 roku w Genewie. Autorem był Giovan Luigi Paschale, waldens - por. C. Buzzetti, C. Ghidelli, La traduzione..., dz. cyt., 108. Autor omawia szerzej inne wydania ze środowisk protestanckich, zwłaszcza włoskich waldensów.

${ }^{37}$ Por. H. Jedin, Storia del Concilio di Trento, Brescia 1949; P. J. Achtemeier, Bibbia in lingua italiana, art. cyt., 134; G. Ricciotti, Bibbia, art. cyt., 1559. Wkrótce tekstem wzorcowym 
ważony i roztropny, jednak konsekwencje okazały się zdecydowanie różne od intencji. Należy jednak wyraźnie stwierdzić, że publikacje Biblii w językach narodowych nigdy nie zostały oficjalnie przez sobór zakazane - problem dotyczył raczej procedury związanej z publikacjami Biblii narodowych autoryzowanych ${ }^{38}$.

Indeks ksiąg zakazanych wydany przez Pawła IV w 1559 roku zawierał już zakaz drukowania, czytania i posiadania wersji Biblii w językach narodowych bez pisemnej zgody Świętego Oficjum ${ }^{39}$. W 1564 roku Pius IV bullą Dominicis gregis zezwala na czytanie Biblii w języku włoskim tylko za osobistą i pisemną zgodą biskupa lub inkwizytora. Od 1569 roku wydanie takiej zgody zostało zarezerwowane dla papieża, chociaż formalnie nadal wyrażali ją biskupi ${ }^{40}$. Katolicy, którzy nie znali łaciny, na parę wieków zostali praktycznie pozbawieni bezpośredniego kontaktu z tekstem Bibliii ${ }^{41}$, jej lektura została zarezerwowana dla viris tantum doctis (tylko uczonych mężów).

W kontekście dyskusji nad postanowieniami Soboru Trydenckiego warto zwrócić uwagę na mało znany fakt z biografii papieża Sykstusa V. Tuż przed swoją śmiercią w 1590 roku zażyczył on sobie, by wydrukowano Biblię w języku włoskim, tak aby wszyscy Włosi mogli ją czytać i by była ona dla nich zrozumiała ${ }^{42}$. Niestety nie zachowały się żadne ślady tej edycji.

stała się Wulgata w wydaniu klementyńskim z 1592 roku.

${ }^{38}$ Por. C. Buzzetti, G. O. Bravi, Edizioni della Bibbia versioni nelle lingue parlate con particolare rifermineto al'Italia, [w:] La Bibbia nell'epoca moderna e contemporanea, dz. cyt., 40.

${ }^{39}$ Święte Oficjum (Sacrum Officium), właściwie Kongregacja Kardynalska Świętej Rzymskiej i Powszechnej Inkwizycji - instytucja powołana w 1542 roku przez papieża Pawła III, odnowiona w 1564 roku na mocy postanowień Soboru Trydenckiego. Był to kościelny sąd najwyższy - por. P. J. Achtemeier, Bibbia in lingua italiana, art. cyt., 134; G. Ricciotti, Bibbia, art. cyt., 1559.

${ }^{40}$ Por. P. J. Achtemeier, Bibbia in lingua italiana, art. cyt., 135. Święte Oficjum rościło sobie takie prawa jeszcze w 1836 roku.

${ }^{41}$ Por. C. Buzzetti, C. Ghidelli, La traduzione..., dz. cyt., 108.

${ }^{42}$ Papież polecił, by taka edycja została wydana przez drukarnię watykańską. Propozycja ta spotkała się z oporem niektórych kardynałów i króla Hiszpanii Filipa II, który wysłał nawet specjalne poselstwo do Watykanu, aby złożyć oficjalny protest. Papież poselstwo zdecydowanie odprawił i ze swego zamierzenia nie zrezygnował - por. J. de Long, Bibliotheca Sacra, t. 1, Parigi 1723, 357-358. 


\section{Wiek XVII}

Biblia Diodati lub Deodati ${ }^{43}$. La Bibbia, cioè i libri del Vecchio e del Nuovo Testamento. Nuovamente traslati in lingua italiana; autor: Giovanni Diodati (1576-1649), ur. w Lucca, ewangelik, uczony, znawca języków starożytnych ${ }^{44}$; miejsce i data: Genewa 1607; źródła: przekład z języków oryginalnych ${ }^{45}$. Dzieło składa się z trzech tomów: Stary Testament, Apokryfy (3 i 4 Księga Ezdrasza orazksięgi deuteronomiczne) oraz Nowy Testament; każdy z nich ma oddzielną paginację. W tomach I i III pojawiają się uwagi na marginesie. Przekład ten zaliczany jest do najlepszych w protestantyzmie ${ }^{46}$. Stał się tłumaczeniem klasycznym, wzorcowym. Autor zaprezentował bardzo dobrą znajomość języka hebrajskiego i dał dowody niezależności od panujących wówczas opinii. Tłumaczenie jest jasne. Niekiedy dla poprawnego oddania oryginalnych treści zastosowane zostały parafrazy. Dzięki wszechstronnym umiejętnościom autora powstało dzieło w pełni odpowiadające ówczesnemu stanowi wiedzy. Wśród przyczyn niezwykłej popularności tego przekładu wylicza się m.in. zgodność niekiedy nawet przesadną, prawie dosłowną z tekstami w językach oryginalnych, umiejętne oddanie klimatu języka włoskiego, ukierunkowanie na przeciętnie wykształconego odbiorę, nastawienie katechetyczne ${ }^{47}$.

W 1641 roku autor opublikował nowe dzieło zatytułowane La Sacra Bibbia tradotta in lingua italiana e commentata. Seconda edizione migliorata ed accresciuta ${ }^{48}$. W nowej edycji zmienił się nie tylko przekład, ale

${ }^{43}$ Por. A. Vaccari, Bibbia, art. cyt., 902; G. Ricciotti, Bibbia, art. cyt., 1559; F. Spadafora, Bibbia, art. cyt., 88; P. J. Achtemeier, Bibbia in lingua italiana, art. cyt., 135.

${ }^{44}$ Wykładał język hebrajski w Szwajcarii na życzenie Téodore’a de Bòze (Beza), następcy Kalwina - por. P. J. Achtemeier, Bibbia in lingua italiana, art. cyt., 135.

${ }^{45}$ Diodati swoją znajomość języków oryginalnych konfrontował z wydaniami łacińskiej Wulgaty, szesnastowieczną erudycją hebrajską, komentarzami Kalwina, angielskimi i francuskimi przekładami genewskimi. Kierował się ponadto natchnionym charakterem swojej pracy - por. P. J. Achtemeier, Bibbia in lingua italiana, art. cyt., 135.

${ }^{46}$ W Nowym Testamencie dostrzega się wyraźne starania autora, by treść ukierunkować na odbiorców protestanckich - por. A. Vaccari, Bibbia, art. cyt., 902.

${ }^{47} \mathrm{~W} 1644$ roku ukazała się drukiem francuskojęzyczna wersja tego przekładu, ale nie odniosła ona sukcesu. Same przypisy zostały przetłumaczone także na język angielski - por. A. Vaccari, Bibbia, art. cyt., 902.

${ }^{48}$ Lekkimi modyfikacjami Biblii Diodati były włoskie przekłady Mattia d’Edberga (Norymberga i Kolonia 1772) oraz Giovanniego Davida Müllera (Lipsk 1774) - por. 
i przypisy dolne (ich treść została wzbogacona i poszerzona). Na końcu wydania dołączono I sacri Salmi messi in rime volgari z własną paginacją. Pozycja była wielokrotnie przedrukowywana aż do początku XX wieku.

\section{Wiek XVIII}

Lepsze czasy dla włoskich przekładów Biblii nastały po 13 czerwca 1557 roku, kiedy to papież Benedykt XIV zezwolił na czytanie tłumaczeń katolickich zaaprobowanych przez Stolicę Apostolską lub opublikowanych pod nadzorem biskupim. Nadal obowiązywało zastrzeżenie, by nie publikować tekstu biblijnego bez dołączonego komentarza autorów katolickich, przede wszystkim Ojców Kościoła. W ciągu dwudziestu lat pojawiły się trzy ${ }^{49}$ nowe różne tłumaczenia Biblii w całości. Najważniejszego z nich dokonał Antonio Martini.

Biblia Martiniego $0^{50}$. La Sacra Bibbia - autor: Antonio Martini (17201803), ur. w Prato; miejsca i daty: Nowy Testament ukazał się w latach 1769-1771 (wydanie 6-tomowe); Stary Testament w latach 1776-1781

A. Vaccari, Bibbia, art. cyt., 902. W XX wieku przekład Diodati zostaje gruntowanie przepracowany. Uwzględniono zmiany wynikające z ewolucji języka włoskiego oraz z ponownej konfrontacji z tekstami w językach oryginalnych. Prac tych dokonała komisja, której przewodził Giovanni Luzzi. W 1924 roku opublikowała ona Versione Riveduta. Wcześniej jeszcze, bo w 1909 roku, powstało stowarzyszenie Fides et Amor propagowane przez Luzziego, które do pracy nad tekstem biblijnym skłaniało wszystkich chrześcijan w nadziei, że uda się wypracować przekład możliwy do przyjęcia przez wszystkie odłamy wyznawców Chrystusa. Owocem prac stowarzyszenia były Nuovo Testamento annotato (1911) i Il Nuovo Testamento e i Salmi. Riuniti in un volume (1917), bardzo rozpowszechnione wśród żołnierzy włoskich w czasie I wojny światowej. Luzzi, niezależnie od prac nad Biblia Diodati, przygotował swoje własne monumentalne dzieło: Bibbia tradotta dai testi originali e annotata wydane w dziesięciu tomach w latach 1921-1930. Najnowsza wersja Diodati rozpowszechniona w 1994 roku nosi nazwę Versione Nuova Riveduta - por. C. Buzzetti, C. Ghidelli, La traduzione..., dz. cyt., 109.

${ }^{49}$ Pierwsze dwa z nich to wydanie Alise Guerra pod nazwiskiem Malermiego (w rzeczywistości jest to dzieło zupełnie nowe) z 1773 roku oraz wydana w Wenecji (1775-1785), a potem w Genui i Neapolu Sacra Scrittura giusta la Volgata in lingua latina e volgare colla spiegazione del senso letterale e del senso spirituale tratta dai Santi Padri e dagli autori ecclesiastici dal Sign. Le Maitre de Sacy (w tym wydaniu tylko wyjaśnienia zostały zaczerpnięte z francuskiego wydania del Sacy) - por. A. Vaccari, Bibbia, art. cyt., 902.

${ }^{50}$ Por. A. Vaccari, Bibbia, art. cyt., 902; G. Ricciotti, Bibbia, art. cyt., 1559-1561; P. J. Achtemeier, Bibbia in lingua italiana, art. cyt., 135; F. Spadafora, Bibbia, art. cyt., 87. 
(wydanie 16-tomowe), całość została ponownie wydana w Neapolu (1771-1781), Wenecji (1781-1786), w Rzymie (1784-1789); źródła: tłumaczenie z Wulgaty w konfrontacji z tekstami w językach oryginalnych.

Wydanie całościowe oprócz tekstu włoskiego i łacińskiego zawiera długie wprowadzenia (ogólne do całego dzieła i specjalne do każdej księgi) oraz obszerne przypisy u dołu strony (mające wzmacniać wiarę i pobożność). Język tłumaczenia jest wierny oryginałowi, ale bez służalczości. Charakteryzuje się dyskretną elegancją, godną szacunku i podziwu. Z tego też tytułu wydanie cieszyło się niezwykłą popularnością ${ }^{51}$. Autor korzystał ze współczesnych mu naukowych komentarzy biblijnych ${ }^{52}$. Jego dzieło przyczyniło się wydatnie do rozwoju i odnowy studiów biblijnych. Podczas pracy autor spotkał się z życzliwą przychylnością papieża Piusa VI, który w specjalnym breve apostolskim ${ }^{53}$ dodawał mu odwagi. Martini już jako arcybiskup Florencji w latach 1782-1792 dokonał nowej edycji swojego dzieła - to właśnie wydanie stało się normą i wzorem dla wielu kolejnych przedruków ${ }^{54}$. Była to najbardziej wśród katolików rozpowszechniona wersja Biblii w języku włoskim aż do Soboru Watykańskiego II ${ }^{55}$.

${ }^{51}$ Accademia della Crusca - stowarzyszenie lingwistyczno-literackie założone 1582 we Florencji. Celem jego działalności było przestrzeganie czystości języka. W latach 1783-1811 włączone zostało do Akademii Florenckiej. Ogromne znaczenie dla procesu kształtowania się ogólnonarodowego języka włoskiego miał wydany przez nie słownik Vocabulario degli Accademici della Crusca (1612), nadal wznawiany. Od 1923 publikuje również prace poświęcone filologii. Zaliczyła ten tekst do swoich zbiorów - por. A. Vaccari, Bibbia, art. cyt., 902.

${ }^{52}$ A. Calmet, Dictionnaire historique et critique de la Bible, 1772, tłumaczenie łacińskie, Wenecja 1766 - por. P. J. Achtemeier, Bibbia in lingua italiana, art. cyt., 135.

${ }^{53}$ Z 17 III 1778.

${ }^{54}$ Np. A. Guera, Wenecja 1773 ('́rodowiska konserwatywne), Nowy Testament z Pistoi (1786-1789) promowany przez bpa Scipione de'Ricca (środowisko postępowe) - por. P. J. Achtemeier, Bibbia in lingua italiana, art. cyt., 135. Również i w późniejszym okresie było podstawą kolejnych tłumaczeń, np. Sales-Girotti (Turyn 1911-1942); G. Castoldi (Florencja 1929); E. Tintori (Albea 1931) - por. F. Spadafora, Bibbia, art. cyt., 87.

${ }^{55} \mathrm{~W}$ samym tylko XIX wieku była wznawiana czterdzieści razy, por. P. J. Achtemeier, Bibbia in lingua italiana, art. cyt., 135. 


\section{Wiek XIX}

Do najważniejszych tłumaczy Biblii w tym okresie należą ${ }^{56}$ :

Gian Bernardino De Rossi - uczony z Padwy. Przetłumaczył niektóre księgi Starego Testamentu: Psalmów (1808), Eklezjastesa (1809), Hioba (1812), Przysłów (1815), Lamentacje Jeremiasza (1823). Edycja zawiera krótkie uwagi filologiczne. Tłumaczenie uchodzi za wyjątkowo wierne oryginałowi, mniej udane pod względem stylistycznym.

Gregorio Ugdulena - ksiądz, patriota sycylijski, wykładowca języka hebrajskiego. Jego dzieło La Sancta Scrittura in volgare riscontrata nuovamente con gli originali ed illustrata con breve commento, nowe w ujęciu i cenne w komentarzach, byłoby niezwykle cennym i ważnym tłumaczeniem, gdyby zostało ukończone ${ }^{57}$. Autor opublikował jedynie Pięcioksiąg, Księgę Jozuego i Księgi Królewskie (Palermo 1859-1861); reszta pozostała w rękopisach $^{58}$. Jego edycja była w zasadzie rewizją wydania Biblii Diodati, dokonaną w świetle najnowszych osiągnięć dziewiętnastowiecznej wiedzy filozoficznej i historycznej.

Carlo M. Curci - zbyt późno zajął się biblistyką, by stworzyć dzieło w pełni dojrzałe ${ }^{59}$. Przetłumaczył jedynie: Il Nuovo Testamento volgarizzato ed esposto in note esegetiche e morali (Turyn 1879-1880, 3 tomy); Salterio volgarizzato dall'ebreo ed esposto... (Turyn 1883); L'Ecclesiaste secondo il testo ebraico. Doppia traduzione con proemio e note di G. Vegni (Florencja 1871). Jego dzieła są owocem solidnej pracy i dużej wiedzy, chociaż w przypadku ostatniej pozycji istnieją spore zastrzeżenia do krytyki tekstu.

Należy w tym miejscu wspomnieć także o przekładach na język włoski dokonywanych przez autorów żydowskich ${ }^{60}$. Pierwsze miejsce

${ }^{56}$ Por. A. Vaccari, Bibbia, art. cyt., 902; G. Ricciotti, Bibbia, art. cyt., dz. cyt., 1561-1562; P. J. Achtemeier, Bibbia in lingua italiana, art. cyt., 135; C. Buzzetti, C. Ghidelli, La traduzione..., dz. cyt., 110. Poza omówionymi w tekście na wzmiankę zasługują: A. Guerra, F. S. Patrizi, N. Tommaseo, G. Vegni, S. Minocchi, L. Costantini, P. Vannutelli, G. Re.

${ }^{57}$ Autor, mimo że był chwalony przez A. Manzoniego i Piusa IX, zajął się polityką i zaniechał dalszej pracy nad swoim dziełem - por. G. Ricciotti, Bibbia, art. cyt., dz. cyt., 1561.

${ }^{58}$ Por. A. Vaccari, Bibbia, art. cyt., 902.

${ }^{59}$ Por. tamże.

${ }^{60}$ Najstarsze rękopisy ksiąg Starego Testamentu przetłumaczonych na język włoski przez Żydów sięgają XV wieku. Były to jednak opracowania skierowane do wąskiego grona odbiorców, współwyznawców, nie miały zatem wielkiego znaczenia i nie odegrały jakiejś szczególnej roli. W XVI wieku wydano L'Ecclesiaste di Salomone nuovamente 
wśród nich zajmuje Isacco Samuele Reggio, autor hebrajsko-włoskiego przekładu Pięcioksięgu (Wiedeń 1821) oraz poetyckiej wersji Księgi Izajasza (Wiedeń 1831). Miejsce szczególne należy do Samuela Davida Luzzato (1800-1865), światowej sławy hebraisty, który po wcześniejszych opracowaniach częściowych wydał w całości La Sacra Bibbia volgarizzata da S. D. Luzzato e continuatori (Rovigo 1872-1875, 4 tomy) ${ }^{61}$.

W kontekście trwających dysput dogmatycznych i moralnych w ramach Kościoła epoki Soboru Trydenckiego (1545-1563), a potem w zderzeniu z ideologią oświeceniową obecność Biblii w życiu wierzących naznaczona była silną perspektywą doktrynalną: nie była ona najważniejszą wśród ksiąg pobożnych, ale z pewnością stanowiła pierwszą pomoc dla działalności katechizmowej ${ }^{62}$. Nieuzasadnionym jest zatem twierdzenie, że po dyskusyjnych decyzjach Soboru Trydenckiego Biblia zniknęła z życia chrześcijańskiego. Wbrew uproszczonym opiniom pozostała bowiem nadal ważnym jego elementem. Relacja tekst-wierzący nabrała jedynie innego kształtu: czytanie tekstów biblijnych oznaczało słuchanie duszpasterza, który wyjaśniał teksty w katechezie, w przepowiadaniu, podczas misji itp.

Na poziomie kultury ludowej, praktycznie pozbawionej możliwości bezpośredniego kontaktu z Biblią, odczuwało się ogromną tęsknotę za tekstem świętym pojmowanym jako świadectwo początków wiary i źródło reformy, która - oczekiwana przez wielu - miała wkrótce nadejść. Włochy nie mogą pochwalić się oryginalnością na polu duszpasterstwa biblijnego, jak np. Francja (XVII wiek) czy Niemcy (XIX wiek). Na mapie krajów „biblijnych” tego okresu można by ją umieścić w rzędzie państw zacofanych. Byłoby jednak rzeczą niesprawiedliwą i zubożającą pominięcie faktu, który stanowi o wyjątkowości włoskiej drogi biblijnej: jest dal testo hebraico tradotto... dall'eccelente fisico [medico] M. David de'Pomi, hebreo (Wenecja 1571). W XVII wieku Ezechia di Rieti wydał Proverbi di Salomone (Wenecja 1617).

${ }^{61}$ Kontynuatorami Luzzato byli m.in. S. Gentiluomo, L. della Torre, B. Consolo, G. Morpurgo, D. Castelli - por. P. J. Achtemeier, Bibbia in lingua italiana, art. cyt., 135-136. Najnowsze tłumaczenie hebrajsko-włoskie ukazało się w latach 1960-1967 w Turynie w wydawnictwie Marietti. Liczy cztery tomy. Promotorem edycji był D. Disegni, tłumaczem A. S. Toaf, S. Sierra i inni. Każdy tom uzupełniony jest dodatkiem zawierającym liczne kolorowe fotografie - por. C. Buzzetti, C. Ghidelli, La traduzione..., dz. cyt., 109.

${ }^{62}$ Por. La Bibbia nell'epoca moderna e contemporanea, dz. cyt., 182-183. 
nim próba utrzymania jedności i wzajemnego oddziaływania Biblii oraz całości znaków tradycji. Dzięki takim zabiegom Biblia była rozpowszechniana poprzez jej równoważniki: kaznodziejstwo, systematyczną i kompletną katechezę, opowiadanie historii świętej, nabożeństwa związane z tajemnicami życia Jezusa, Maryi i świętych. Były to zatem czasy nie tyle studium nad Pismem Świętym, co zaciekawienia i zachwytu nad osobami i wydarzeniami tworzącymi biblijną historię.

Rzym

RYSZARD WRÓBEL OFMCONv

\section{Słowa kluczowe}

Biblia, Pismo Święte, ewangelia, źródło, tłumaczenie, przekład, edycja, wydawca, redakcja, komentarz, egzegeza, Włochy

\section{Summary}

Bible translations into Italian (XV-XIX century)

The author discusses, in chronological order, all the major translations of the Bible which were published in Italian from the beginning of the fifteenth to the late nineteenth century. By definition he did not consider translations done for partial or specialized studies (e.g. only the Gospels, only the Psalms, the Bibles for children, etc.). The list includes eight items. In a presentation of each of them the author uses a very homogeneous pattern to help the reader to see similarities and differences between releases. The information includes data such as: name or title of work, author's name, place and date, publisher's name, names of translators, editors, source of translation, editing characteristics, and other observations. The whole presentation is provided with a short introduction which allows to place the Bible editions in the proper context and with the conclusion in which we become acquainted with the specificity and exceptionality of the Italian Bible way in the discussed period.

\section{Keywords}

Bible, Holy Scripture, Gospel, source, translation, editing, editor, commentary, exegesis, Italy 